\title{
Preface to the Issue
}

\section{Małgorzata Bogaczyk-Vormayr}

(Adam Mickiewicz University in Poznań, Institute of Philosophy, bogaczyk@amu.edu.pl)

\section{Monika Małek-Orłowska}

(Wrocław University of Technology, Department of Humanities, monika.malek@pwr.edu.pl)

We present an "ancient issue“ of "Ethics in Progress", in which we attempt to show how the studies in classics and in ancient philosophy should be and could be an inspiration for ethical reflection. Classical texts are of lasting importance and relevance in their ontological, epistemological as well as ethical conclusions. In our point of view an interpretation historically, philologically - but above all the reception of ancient concepts are of utmost relevance for current studies in moral philosophy. In the $20^{\text {th }}$ century a few historians of philosophy suggested the understanding of ancient philosophy as a practical philosophy, among them professor Juliusz Domański (Warsaw) whose article in Polish we publish in this issue of "Ethics in Progress". The paper, My Adventure with Practicism [Moja przygoda z praktycyzmem], recapitulates the main idea of his scientific work: "practicism" both as a topic and as a sense of philosophy or, more precisely, of philosophical life. The author of $L a$ philosophie, théorie ou manière de vivre? Les controverses de l'Antiquité à la Renaissance (Fribourg-Paris 1996) was invited in 1990 by Pierre Hadot to Paris, where at the Collège de France he delivered lectures on philosophy as practicism, and since then his role in the new interpretation of classical philosophy has been unquestioned. To quote Domański from the abstract of his contribution to our volume: "When I relate today, and once again explain the sense of my studies on practicism, I do it to inspire young ethicists and philosophers to search new terms and definitions for better, possibly well-aimed, description of the phenomena and contents, which I call 'practicism'”.

That is the reason we have invited both professors in classics and philosophy who are highly esteemed in the academia and very young scholars finishing their doctoral dissertations and starting their academic career to contribute to the presented volume, Ancient Ethics Interpretation and Reception. Our aim is to build a bridge between generations and various, even if diverging, views on the same or similar concepts. For that reason it was also important for us to present a selection of papers in English as well as in Polish. It was Małgorzata Bogaczyk- 
Vormayr's idea to connect the authors she had known as lecturers from her study time ${ }^{1}$ with her younger colleagues from the Adam Mickiewicz University of Poznań. Young researchers who publish in our issue of "Ethics in Progress" are already familiar to the journal - Aleksandra Mathiesen and Filip Bardziński, Ph.D. candidates at the University of Poznań, both have lately been authors and co-editors of "Ethics in Progress".

We hope very much that this small collection of papers on the interpretation and reception of selected ancient concepts will become of your interest. Our focus has been put on practical philosophy, with the concepts of justice, politics, paideia, goodness and arete as most representative. Also, some of the positions that are generally understood as metaphysical topics, here adopted more anthropological and ethical characteristics. The opening text Moja przygoda z praktycyzmem [My Adventure With Practicism] is thus the presentation of "practicism", the genuine idea of Juliusz Domański. The author characterizes "personality of philosopher" as having two equally important parts - the one related to theoria and the other to praxis. The ideal compilation of scientific knowledge and ethical disposition (recognized in the ancient and patristic literature as bios theoretikos and bios praktikos) becomes in his interpretation of ancient writings, e.g. of Nicomacheian Ethics, a form of philosophical and moral imperative to "create yourself into an ethical subject" ("samotwórczość podmiotu etycznego"). Moreover, this self-creation - as self-knowledge, moral dilemma, ethical conflict, faith against injustice appeared a significant topic in the ancient literature, what is showed by Bruce D. MacQueen (Tulsa) and Filip Bardziński in their contributions.

In Naïve Justice in the Ancient Greek Novel Bruce D. MacQueen explicates Aristotle's term aistheneia (Poetics) in the sense of "naïve justice" and Socrates's definition of dikaiosyne (Rep. II Book). His goal is to adopt those two concepts for a new interpretation of some wellknown motives from the ancient Greek novels. The episodes - affiliated to drama-situation, in generally called "trail scene" - came from Chariton's Chaereas and Callirhoe, Tatius's Leucippe and Clitophon, Longus's Daphnis and Chloe. In the author's opinion, the three selected episodes throw a light on the meaning of dikaiosyne in the way that both meanings of dikaiosyne are accented: public and private/personal. MacQueen seems to elaborate on the ancient texts with the help of a very "Aristotelian method". He is interested in the impact and value of words (how we describe our experiences, how we definite the world) and also how the philosophical concepts - e.g. of justice - are faced with human life, or in other words: how we move on from

\footnotetext{
${ }^{1}$ M. Bogaczyk-Vormayr attended a lecture of Latin Literature by professor Bruce D. MacQueen at the University of Silesia in 2001 and a lecture of Latin Comedy by professor Juliusz Domański at the University of Warsaw in 2004; in 2010 being a young fellow at the ifz Salzburg she invited doctor Wilhelm Blum, a co-donator of ifz and a reviewer of research projects, to be a co-author in a patristics book project.
} 
the exemplar situation to the principle, how the life experience takes umbrage at philosophical thinking.

Literary examples as an argument and explication of some philosophical concepts have also been employed by Filip Bardziński in his comprehensive paper on transformations and clarifications of hybris - Pojęcie hybris w kulturze i filozofii greckiej [Hubris in Ancient Greek Culture and Philosophy]. The author provides an exhaustive resume on exegeses of hybris in Mythology, Poetry and Drama (e.g. Homer, Aeschylus, Pindar, Euripides) and likewise in Historiography and Philosophy (e.g. Herodot, Aristotle, Aischines, Demosthenes). His key-idea however is to assign the phenomena of hybris to not only a rhetorical interpretation (most obvious for the political Greek texts), but rather to show hybris as a worthwhile category for ethical reflection in generally, that includes also modern ethics and anthropology. The presented text originally was developed as a seminar essay, in the class of professor Marian Wesoły (University of Poznań), but its final version is extended by the bioethical excurse (bioethics is the main area of Bardziński's research work), from which we can relevantly see the classical question on hybris as a cultural construct or as a typical characteristic of human being.

As much as the specific role of rhetorical presentation of human goals and affections reported by Filip Bardziński, the rhetoric itself becomes a topic for the next paper, authored by Aleksandra Mathiesen: Edukacja retoryczna jako element kształtowania mądrości politycznej [Rhetorical Education As a Component of the Formation of Political Wisdom]. Also here we find not the first most popular Greek meaning of rhetoric - to use it in oratorical practice - but rather its deep significance and importance as an educational value. Greek paideia marks yet the model how two ideas/ideals must absolutely coexist - one of a good education and second of being a good (educated, "formed", ethical, just) citizen. In that manner Mathiesen reconstructs and interprets understanding of rhetoric by Plato (alethos politike techne), Aristotle (e.g. proaíresis), and Isocrates (logon paideia).

Wilhelm Blum (Munich) presents the reception of epicurean and stoical thought in Thomas More and Jacob Balde. The latter writers were also philosophers, historians and politicians - both were speakers and advisers to the sovereigns. However in Humanistic Poets And Classical Philosophy Blum focuses on their lyrical texts analyzing the ethical dimensions of Epigram 119 by Morus and Carmina Lyrica III, 12 by Balde. This way Blum manages to find the right balance between the ethical attitude and the task of a writer, what obviously belongs to the sense of 'practicism'. Blum deals with original texts, interpreting the concepts, views and modern relevance of Morus and Balde directly from their words. We share the same idea on how to work with classical concepts: the historical study being the foundation for research work and the research focusing not on the endless list of interpretations (though hardly ever a journal 
paper is a full interpretation, rather a new voice in the discussion), but instead on the classical text itself and the question of its possible abiding relevance. Such method of research and didactics is illustrated by the two last papers: Parmenides' Poem: Riddle in B5 by Małgorzata Bogaczyk-Vormayr and $\boldsymbol{O}$ podstawowych stanowiskach $w$ etyce antycznej [About the Fundamental Views in Ancient Ethics] by Edmund Husserl, translated by Bogaczyk-Vormayr (Polish Bonus).

In her reading of Parmenides's Poem "On Nature" Bogaczyk-Vormayr formulates the opinion that the main thesis of the Poem is to be found in B5: "For me, where I am to begin from is the same for to there I will come back again". Bogaczyk-Vormayr claims that in B5 we should identify the essential ancient motive of the self-knowledge: "the inner Way of Truth". This brings us somehow to the question on how that ontologically fundamental ancient text should be read also as an anthropological and ethical testimony. Indeed, this could be again an imperative of 'practcism'. The very same purpose was the reason for the author when she decided to present Husserl's lecture on Socratic Ethics.

The concluding and crowning text comes from Husserl's course "Einleitung in die Ethik" ["Introduction into Ethics"] from the spring semester 1920, repeated and extended in the spring semester 1924, each time in Freiburg. As Bogaczyk-Vormayr emphasizes in her preceptive introduction, Husserl does not evoke any historical paradigm, he does not want to - simply said - be a historian of philosophy; on the contrary, Husserl presents his view of ethics, which we should call a phenomenological one. That means he presents a critical history of philosophy - his analyses are focused on philosophical ideas and only their philosophical potential is what matters to him. In the context of the idea of 'practicism' and our goal to show how ancient ethics could be approached in the reception - that not only as an interpretation or historical analysis Husserl's portrait of Socrates as a reformer of philosophy and philosophical practice seems to be very important together with his explanation of Socratic criticism of sophistic and empiricism, but also Socrates's importance for the modern philosophy, e.g. for Kant.

We believe the lecture of Husserl, however written almost a century ago, in the epoch of philosophy clearly different from ours, provides us with a very good example for the timeless validity of classical concepts of ethics. Our hope also extends to the belief that we manage to justify this issue of "Ethics in Progress" precisely with this validity. At the same time we want to invite the readers to see how it was and still can be to constantly first discover some ideas in the ancient texts, so then to reveal them in new interpretations and receptions. 